\title{
ECONOMIC EVALUATION OF RECOVERY OF PARTS OF FOREIGN EQUIPMENT BY GAS-DYNAMIC SPRAYING
}

\author{
Sergey Strebkov, Aleksandr Turyanskiy, Andrey Bondarev, Alexey Slobodyuk \\ Belgorod State Agricultural University named after V. Gorin, Russia \\ serwastr@gmail.com, bsaa-inter2@mail.ru, av.bondarev@gmail.com, aspl22@yandex.ru
}

\begin{abstract}
Currently, for imported machines, a full-fledged technical service is provided mainly by authorized dealers. This makes the service very expensive due to the monopoly of the manufacturer. The increase in the cost of maintenance in the percentage of the cost of equipment is directly proportional, and for some tractors can reach amounts of several hundred thousand rubles. Analysis of the cost of restoring the working capacity of foreign equipment shows, on average, a double overestimate of the cost of spare parts in the overall structure of the cost of restoration.We propose a method for restoring the cover of the John Deer 7830 transmission manifold. The defect of this part, having the highest repeatability, is a strong wear and tear on the flat working surface of the oil pump attachment. The described defect results in breaking the end seal of the gear pump and, in accordance with the manufacturer's requirements, necessitates replacement of the new part, which is very expensive for the owner of the tractor.The operation of the restored parts on the tractors showed the correctness of the choice of the recovery method, because good results on adhesion and wear-resistance were obtained.The economic analysis of the expediency of restoring parts has shown that the replacement of imported equipment by restoration depends on a clear understanding by the service organizations of the task of ensuring the working condition of foreign equipment in the territory of Russia, when carrying out the Doctrine of Food Security of the State. Experience in the implementation of the restored parts showed that with an estimated profitability of $77 \%$ in the operation of machinery, the profitability from the sale of the self-restored parts of the service department was more than $250 \%$. Similar results are observed for some other parts (semiaxes, axes, radiators, etc.).
\end{abstract}

Keywords: recovery efficiency, cover, gas-dynamic spray technology, optimum process parameters, economic efficiency technologies.

\section{Introduction}

The development of food production and agricultural raw materials in the Russian Federation is in line with the strategic tasks of the state and, above all, the problem of ensuring food security, especially in the current geopolitical realities.

It is impossible to achieve this goal without innovative technologies in crop and livestock production. At the same time, all intensive technologies are built on the use of modern highperformance and economical tractor technology and technological machines [1]. In fact, in agriculture, this is one of the main ways to increase productivity, increase gross harvest and, as a consequence, reduce the cost of production, which makes it possible for domestic agricultural producers to be competitive in the world market.

Domestic production of high-tech agricultural machinery does not provide the needs of the farms in it. Besides, the indicators of its reliability in operation remain low. In aggregate, this has become a serious factor in the low economic performance of the industry. As a result, farms are forced to purchase foreign equipment, which is more expensive, but at the same time, more qualitative. Demand for it and its implementation have increased several times in all positions.

Studies [1] indicate that the optimum service life of tractors is from 4 to 7 years, however, in the current economic conditions, it is extremely difficult to keep it. Therefore, a preventive maintenance and repair system should be used actively to increase the service life of machines.

At the same time, the problem of technical service is more acute for imported cars since they are less repairable and worse fit into the existing system of maintaining a fleet of vehicles in a functioning and efficient state.

For imported cars, a full technical service is provided mainly by authorized dealers. This makes the service very expensive due to the monopoly of the manufacturer. The increase in the cost of maintenance is directly proportional to the cost of equipment (Figure 1) and for some tractors can reach amounts of several hundred thousand rubles. 




Fig. 1. Costs (\%) for maintenance of equipment in operational (operable) state

Analysis of the cost of restoring the working capacity of foreign equipment (Figure 2) shows, on average, a double overestimate of the cost of spare parts in the overall structure of the cost of restoration, which does not contradict the data [2].

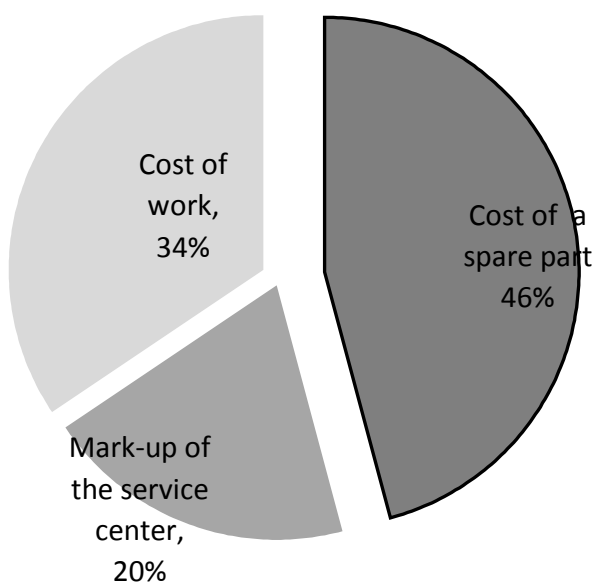

Fig. 2. Cost of replacing parts by authorized dealer service center

On the one hand, the monopoly of machinery manufacturers dictates the pricing policy for spare parts and, on the other hand, the geopolitical events of 2014 showed that political decisions often prevail over reasonable economic logic and business interests. This is unacceptable from the point of view of the independence of producers.

One can find a way out of this situation, which is to increase the efficiency of technical service of imported machines, to reduce operating costs and to weaken the price diktat, by restoring the parts. Analysis of the types of failed parts and the nature of their wear and tear showed that the organization of their recovery is possible considering the specific features of defects, existing methods of recovery and subsequent machining.

At the same time, there is no available design, technological and repair documentation for imported machines, which limits the possibility of developing technological processes for the restoration of worn-out parts. Therefore, it is often possible to develop a full-fledged technological process for restoring the parts of an imported machine only in the result of sufficiently serious scientific and developmental work.

\section{Materials and methods}

In the scientific-production laboratory of restoration of worn parts of the Faculty of Engineering of the Belgorod State Agricultural University work is underway to replace parts of imported equipment by restoring their life. 
So, we have developed a technological process for repairing the cover of the John Deer 7830 transmission manifold (Figure 3). The defect of this part, which has the highest repeatability, is a strong wear and tear on the flat working surface of the oil pump attachment (Figure 4). The reason for such failures is the ingress of metal particles from the collapsed bearings under the pinion.

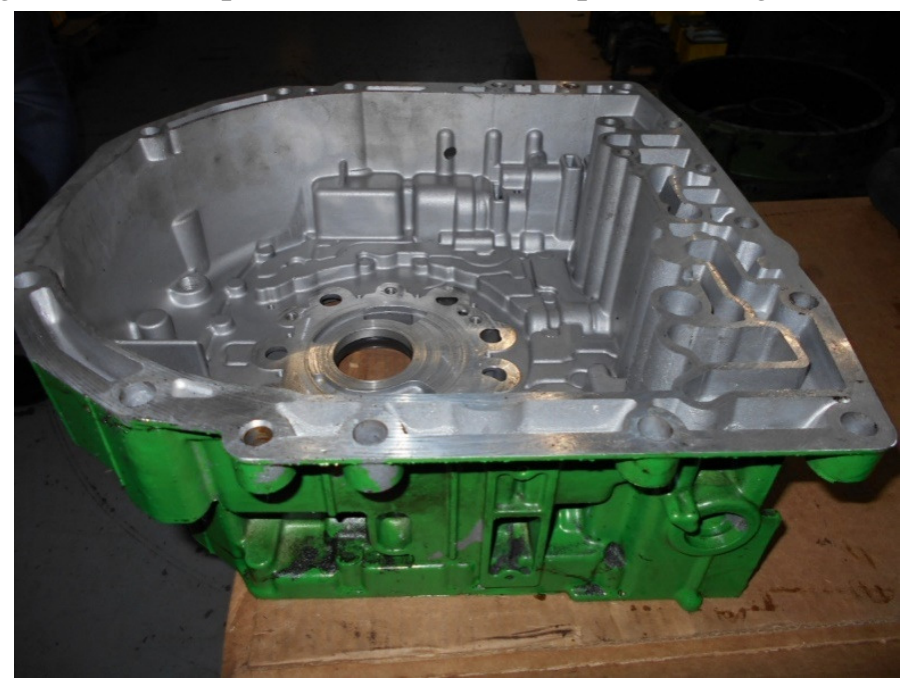

Fig. 3. General view of manifold cover

The cover is made of aluminum alloy and is a thin-walled construction of complex shape, performing several functions. The part is a power element that provides the fastening and mechanical seal of a gear oil pump, and acts as a hydroplate with cast oil channels.

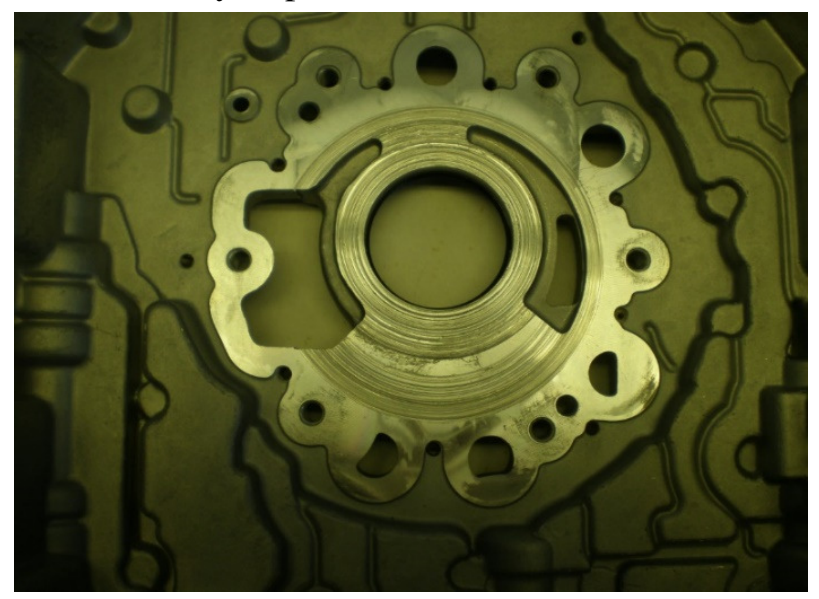

Fig. 4. Seats of leakage failure

The resulting defect of this part, as described above, leads to a breakdown of the mechanical seal of the gear pump and, in accordance with the manufacturer's requirements, necessitates replacement of the new part, which is very expensive for the tractor owner.

The task of restoring the efficiency of the transmission manifold cover R289609 is complicated by several factors. Thus, it is impossible to remove a layer of material from the damaged surface to the depth of wear. In this case, in order to maintain the inner size (height) of the cover, it is necessary to remove the same thickness of material from the outer flange, and this disrupts the overall height of the part and changes the overall size of the gearbox, which is unacceptable.

Thin-walled construction made of aluminum alloy does not give the opportunity to apply surfacing of a layer of material to the place of a defect. The intense thermal impact leads to warping and discontinuity of the flatness of the mounting surface.

We have proposed a recovery method that includes three stages - special preliminary preparation ("activation") of the worn surface, gas-dynamic spraying of the layer [3], which includes the allowance for processing, and machining the working surface in size to the required roughness. 
Preliminary cleaning and abrasive preparation of the part surface, as well as spraying of the reducing layer, were carried out at the DIMET 405 serial unit $[4 ; 5]$.

Aluminum oxide powder K-00-04-16 was used to activate the surface, and aluminum-zinc composition A-20-11 was used for spraying.

When choosing the modes of application of the powder material, we were guided by the need to ensure high adhesion at the beginning of the process with reduced application modes, followed by an increase in the thickness of the applied layer.

For accurate positioning of the application site and the maximum thickness of the reducing coating, we used an individually manufactured template mask. The same mask protected from damage the non-worn part of the working surface, on which the tool was later based while machining.

The machining was carried out on a milling machining center DUGARD 1000VMC by a horizontal milling method. The basing was carried out along the plane from the side of the hydroplate. Feature machining to the nominal size was the presence of a part of the base non-uniform surface of the mating plane of fastening of the pump on which the tool for removing the allowance for processing was put. Milling was carried out in two passes to the final roughness Ra1,25.

Figure 5 shows (from left to right) the surface of the part before recovery, with a sprayed surface and after machining.

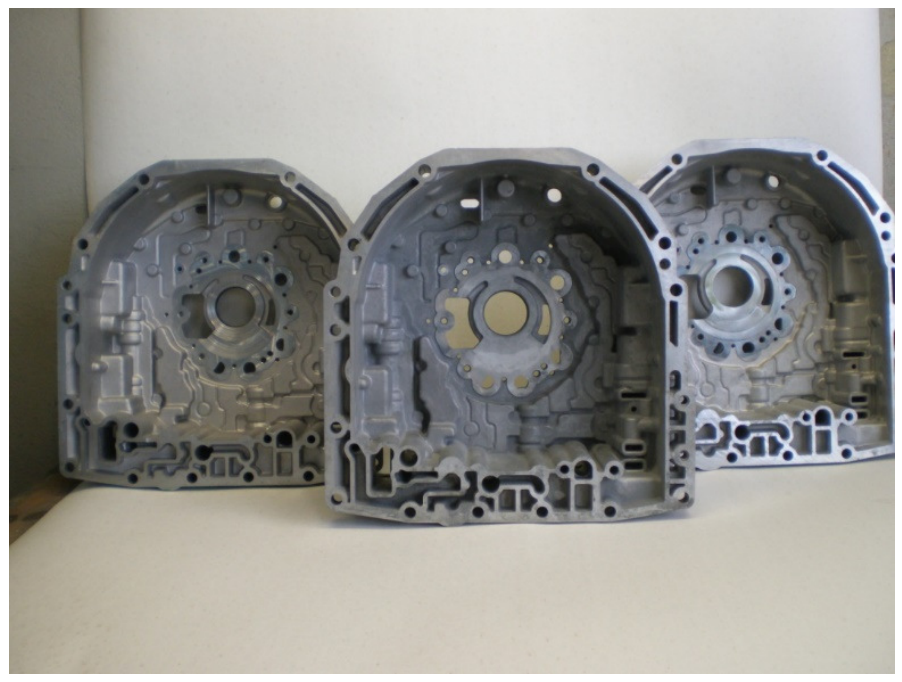

Fig. 5. Surfaces of collector cover at different stages of recovery

The operation of the restored parts on the tractors showed the correct choice of the recovery method, since good results on adhesion and wear resistance were obtained.

Basic data for determining the economic efficiency of recovery are presented in Table 1 [6].

The calculation of the economic efficiency of the recovery (E) is carried out according to the procedure [7-10]:

$$
E=\left[\left(C_{1}+E_{N} \cdot K_{1}\right) \cdot \frac{P_{1}+E_{N}}{P_{2}+E_{N}}-\left(C_{2}+E_{N} \cdot K_{2}\right)\right] \cdot A_{2},
$$

where $C_{1}, C_{2}-$ cost price of restoration according to the existing and proposed technological processes, respectively, RUB per part;

$K_{1}, K_{2}$ - specific capital investments for the acquisition and installation of repair and technological equipment for the existing and proposed technological processes, respectively, RUB per part;

$E_{N}$ - coefficient of effectiveness of capital investments, $E_{N}=0.15$;

$P_{1}, P_{2}$ - values reverse to useful lives of coupling restored by the existing and proposed technological processes, respectively;

$A_{2}$ - annual volume of restoration of parts according to the proposed technological process, pcs. 
Initial data for calculation of economic efficiency (in prices 04.2018)

\begin{tabular}{|c|c|c|c|c|c|c|c|}
\hline Name of a part &  &  & 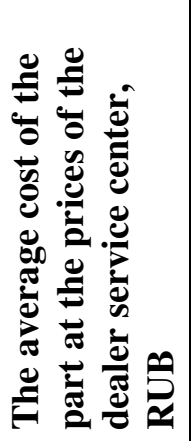 &  &  &  &  \\
\hline $\begin{array}{l}\text { Gearbox manifold } \\
\text { cover of the John } \\
\text { Deer } 7830\end{array}$ & R289609 & 191 & 100065.00 & 155000.00 & 0.85 & 1200 & 6000 \\
\hline
\end{tabular}

To compare the economic efficiency of capital investments, we calculate the indicator of the minimum of the given costs by the formula [7]:

$$
C_{i}+E_{N} \cdot K_{i} \rightarrow \min ,
$$

For the basic version, we accept the replacement of the part R289609 "Gearbox manifold cover" of the 7830 tractor for a new one in the dealer service center.

In determining the economic efficiency, the following mode of operation of the research and production laboratory for the restoration of worn parts was adopted:

- number of working shifts- 1 shift,

- duration of the shift $-8 \mathrm{~h}$,

- number of working days a week -5 days,

- workweek $-40 \mathrm{~h}$,

- number of working days per year - 250 days,

- duration of leave-24 working days.

The annual cover repair program (A) for the proposed variant and the base one is the same and is equal to

$$
A=N \cdot K_{\max }^{P},
$$

where $N$ - number of units of equipment having similar structural elements in the territory serviced by the dealer service center, pcs;

$K^{P}{ }_{\max }$ - highest coefficient of occurrence of a defect.

The annual program for the restoration of covers with $N=191$ and $K_{\max }^{P}=0.85$ is $A=162$ pieces.

The inverse of the lifetime of the mates to the renewed resource, replacing the new part with the restored part, is determined from the ratio:

$$
P_{1}=\frac{T_{1}}{W_{1}}, \quad P_{2}=\frac{T_{2}}{W_{2}},
$$

where $W_{1}, W_{2}-$ the average overhaul resource of conjugation of a new part and with the part restored according to the proposed variant.

For a new and restored part, the average annual operating time is $T=1200$ moto-h.

$$
P_{1}=\frac{1200}{6000}=0.2 \quad P_{2}=\frac{1200}{3000}=0.4 \text {. }
$$


The cost price of the new part is equal to the selling price in the dealer service center $C_{1}=100065$ RUB .

The cost of restoring the cover is determined by the formula:

$$
C=C_{z p}+C_{m}+C_{t z}+C_{e l}+C_{a}+C_{f}+C_{p}
$$

where $C_{z p}$-wages of production workers, RUB ;

$C_{m}$ - cost of materials, RUB ;

$C_{t z}-$ transportation and procurement costs, RUB ;

$C_{e l}$ - electricity costs, RUB ;

$C_{a}$ - depreciation costs, RUB ;

$C_{f}$ - factory costs, RUB ;

$C_{p}$ - other deductions, RUB .

Wages of production workers are defined as:

$$
C_{z p}=C_{b a z}+C_{d o p}+C_{n z p},
$$

where $C_{b a z}$ - basic wages of industrial workers, RUB ;

$C_{d o p}$ - additional wages, RUB ;

$C_{n z p}-$ accruals for labour payment, RUB .

The calculation of the basic salary for the proposed technological process was carried out based on the time norms for performing operations and the minimum possible tariff rate of the worker:

$$
C_{b a z}^{2}=C_{t s}^{2} T_{t r}^{2} K_{T},
$$

where $C_{b a z}^{2}-$ hourly tariff rate of the work performed, RUB per h;

$T^{2}{ }_{t r}$ - piece time to restore one part, $\mathrm{h}$.

The minimum hourly rate of the first category is determined on the basis of the minimum wage (SMIC), which is established by law and is now 11163 RUB. [11].

$$
C_{t s}^{2}=\frac{S M I C}{F_{m n w t}}
$$

where $\quad S M I C-$ minimum wage, RUB;

$F_{\text {mnwt }}$ - maximum monthly nominal working time fund, equal to 192 hours.

Then we get $C_{t s}^{2}=11163 / 192=58.14 \mathrm{RUB} \cdot \mathrm{h}^{-1}$. For the offered technological process all works are carried out by workers of the fourth and fifth categories, for whom the hour tariff rate makes $C_{t s}^{2}=58.14 \cdot 2.35=136.63 \mathrm{RUB} \cdot \mathrm{h}^{-1}$. Piece time for restoration of one cover $T^{2}{ }_{t r}=1.2 \mathrm{~h}=72 \mathrm{~min}$., then the main salary is equal to: $C_{b a z}^{2}=1.2 \cdot 136.63=163.96$ RUB.

Additional wages are calculated:

$$
C_{d o p}=C_{b a z} \cdot 0,1,
$$

Then $C_{d o p}^{2}=163.96 \cdot 0.1=16.40$ RUB.

Social contributions are calculated using the formula:

$$
C_{n z p}=0,302 \cdot\left(C_{d o p}+C_{b a z}\right),
$$

Then $C_{n z p}^{2}=0.302 \cdot(163.96+16.40)=54.47$ RUB.

The wages of production workers according to the proposed technological process are:

$C^{2}{ }_{z p}=163.96+16.40+54.47=234.83$ RUB .

The cost of materials is calculated using the formula: 


$$
C_{M}=\sum M_{i} \cdot C_{a p i},
$$

where $M_{i}$ - consumption of materials, $\mathrm{kg}$;

$C_{a p i}-$ cost of applied materials, RUB.

The time of application of the compensating layer to one part based on the application rate of $1.34 \mathrm{~g} \cdot \mathrm{min}^{-1}$ is 72 minutes.

The consumption of compressed air for the restoration of one part at a feed rate of $0.45 \mathrm{~m}^{3} \cdot \mathrm{min}^{-1}$ for the above period is $0.45 \mathrm{~m}^{3} \cdot \mathrm{min}^{-1} \cdot 72 \mathrm{~min}=32.4 \mathrm{~m}^{3}$. With a compressor capacity of $100 \mathrm{~m}^{3} \cdot \mathrm{h}^{-1}$, the cost of compressed air is $4.85 \mathrm{RUB} \cdot \mathrm{m}^{-3}$.

The costs of materials for the restoration of the cover are presented in Table 2.

Transportation and procurement costs are calculated using the formula:

$$
C_{t z}=1.2 \cdot C_{t r v},
$$

where $C_{t r v}$ - residual value of the repair fund, RUB.

The residual value of the repair fund is calculated using the formula:

$$
C_{\text {trv }}=0.03 \cdot C_{1} \text {, }
$$

where $C_{1}-$ cost of a new transmission manifold cover, RUB.

Materials used in the existing technological process

\begin{tabular}{|c|c|c|c|}
\hline Name of material & $\begin{array}{c}\text { Standard for one } \\
\text { product }\end{array}$ & $\begin{array}{c}\text { Price, RUB per } \\
\text { unit. }\end{array}$ & $\begin{array}{c}\text { Price for one } \\
\text { product, RUB. }\end{array}$ \\
\hline The sprayed powder A-20-11 & $0.10 \mathrm{~kg}$ & 1100 & 110.00 \\
\hline Labomid & $0.6 \mathrm{~kg}$ & 20 & 12.00 \\
\hline Compressed air & $32.4 \mathrm{~m}^{3}$ & $\begin{array}{c}48.5 \mathrm{RUB} \cdot \mathrm{h}^{-1} \\
\left(4.85 \mathrm{RUB} \cdot \mathrm{m}^{-3}\right)\end{array}$ & 157.14 \\
\hline Total $\mathrm{C}_{M}$ & - & - & 279.14 \\
\hline
\end{tabular}

The average cost of a new transmission manifold cover at 2018 prices is: $C_{1}=100065$ RUB, then the residual value of one lid is $C_{t r v}=0.03 \cdot 100065=3001.95 \mathrm{RUB}$, and transport and procurement costs will be: $C_{t z}=1.2 \cdot 3001.95=3602.34$ RUB.

In the case of cooperation with a service centre for the repair of imported equipment, a repair fund may be transferred at no charge, that is $C_{t z}=0$.

The applied processing equipment for the existing and offered methods is given in Table 3.

Table 3

Equipment used in the technological process of recovery

\begin{tabular}{|c|c|c|c|}
\hline Name of equipment & Number, pcs. & Power, $\mathbf{k W t}$ & $\begin{array}{c}\text { Unit cost of } \\
\text { equipment, RUB }\end{array}$ \\
\hline Set of equipment DIMET-405 & 1 & 3.3 & 345740.00 \\
\hline Compressor & 1 & 8.7 & In stock \\
\hline Washing machine & 1 & 2 & In stock \\
\hline
\end{tabular}

Thus, the cost of the equipment of the proposed process will be equal to :

$C_{o}{ }^{1}=0$ RUB, $C_{o}{ }^{2}=345740.00$ RUB.

Power of energy consumers: $P^{2}=14 \mathrm{~kW}$

The cost of electricity per part is calculated by the formula: 


$$
C_{e l}=\frac{P \cdot P_{e l} \cdot K_{c} \cdot T_{p}}{A},
$$

where $P$-capacity of power consumers of the electric power respectively, $\mathrm{kW}$;

$P_{e l}-$ cost of $1 \mathrm{kWh}$ of electricity, RUB $(\mathrm{kW} \cdot \mathrm{h})^{-1}\left(P_{e l}=4.50 \mathrm{RUB} \cdot(\mathrm{kW} \cdot \mathrm{h})^{-1}\right)$;

$T_{p}$ - average annual electricity consumption, $\mathrm{h}\left(T_{p}=0.83 \mathrm{~h}\right)$;

$K_{c}$ - coefficient that takes into account the loading and efficiency of power equipment $\left(K_{c}=0.75\right)$.

Then we get $C_{e l}{ }^{2}=14 \cdot 4.5 \cdot 0.75 \cdot 0.83 / 1=39.22 \mathrm{RUB}$.

Depreciation costs are calculated using the formula:

$$
C_{a}=\frac{0,08 \cdot C_{O}}{A},
$$

where $C_{o}$ - book value of equipment, RUB.

Then we get $C_{a}^{2}=0.08 \cdot 345740 / 162=170.74$ RUB.

General factory expenses are accepted in the amount of $350 \%$ :

$$
C_{z}=3.5 \cdot C_{z p},
$$

Then the factory deductions for the proposed technological process will be

$$
C_{z}^{2}=3,5 \cdot 234.83=821.98 \text { RUB. }
$$

Other deductions are calculated by the formula:

$$
C_{p}=0.15 \cdot C_{M},
$$

Then other deductions for the proposed technological process will be $C_{p}=0.15 \cdot 279.14=$ $=44.57$ RUB

The cost price of repairing the cover by supersonic spraying for the proposed technological process according to the formula (4) is $C^{2}=234.83+279.14+3602.34+39.22+170.74+821.98+$ $+44.57=5192.82$ RUB.

Subject to the zero cost of the repair fund (36020.34 rubles.) $C^{2}=1590.48$ RUB.

Taking into account the subsequent machining the cost recovery is expected to increase by 2 times:

- $\quad$ with the cost of repair fund $2 \cdot 5192.82=10385.64$ RUB.

- without the cost of repair fund $2 \cdot 1590.48=3180.96$ RUB.

Specific capital investments are calculated as:

$$
K=\frac{C_{b}}{A_{2}},
$$

Then the specific capital investments for the existing and proposed technological processes are equal to: $K_{2}=345740 / 162=2134.20$ RUB.

In order to compare the economic efficiency of capital investments, we calculate the minimum of the listed costs by the formula (2):

- $\quad$ with the cost of the repair fund $10385.64+0.15 \cdot 2134.20=10705.77$ RUB;

- without the cost of repair fund 3180.96 + 0.15·2134.20 = 3501.09 RUB.

We calculate the economic feasibility of repair by the formula: 


$$
\frac{C_{N}-C_{r v}}{T_{n}} \geq \frac{C_{p}+E_{N} \cdot K_{y}}{T_{p}},
$$

We get $\frac{100065-3001.95}{6000} \geq \frac{10385.65+0.15 \cdot 2134.20}{3000}$ and $16.18>>3.57$.

Since the inequality condition is satisfied, the restoration of the cover can be considered economically feasible. Assuming the provision of $50 \%$ maintenance of the resource (instead of 6000 moto-h - 3000 moto-h), the purchase of the restored part is 4 times more economical than the new one.Economic efficiency from introduction of the offered technological process for the enterprise on repair of import equipment according to the formula (1) will make:

$$
E=\left[100065 \cdot \frac{0.35}{0.55}-(10385.65+0.15 \cdot 2134.20)\right] \cdot 162=8581455.34 \mathrm{RUB}
$$

or 52971.95 RUB for one restored item.

After the organization of the recovery process at the Belgorod State Agricultural University at the implementation price for the enterprise for the repair of imported equipment $2 * 10385.65=20771.30$ RUB economic efficiency will be

$$
E=\left[100065 \cdot \frac{0.35}{0.55}-(2 \cdot 10385.65+0.15 \cdot 2134.20)\right] \cdot 162=6898980 \mathrm{RUB}
$$

or 42586.30 RUB for one restored item.

If the resource of the restored part is guaranteed equal to the resource of the new one(6000 moto$\mathrm{h})$, the economic efficiency from the introduction of the restoration technology of the cover will be

$$
E=(100065-21091.43) \cdot 162=12793718.34 \text { RUB. }
$$

or 78973.57 RUB for one restored item.

Economic efficiency for the University from the sale of the recovered cap with 15 per cent return will be $10385.65+0.15 \cdot 2134.20=\mathbf{1 0 7 0 5 . 7 8}$ RUB . For the program of 162 parts -1734336.36 RUB.

Without the cost of the repair fund, the economic effect can be increased by $60 \%$, i.e. it will be 2890560.6 RUB or 17843 RUB for one part.

The payback period of additional capital investments is determined by the formula

$$
T_{o}=\frac{K_{D}}{E},
$$

where $K_{D}$ - additional capital investments, RUB .

The amount of additional capital investments is $=34570$ RUB .

Then we get $T_{o}=345740 / 1734336=0.20$ year.

In order to fully compensate the cost of the DIMET-405 installation, it is enough to restore 23 parts R289609 "Gearbox manifold cover" of the tractor 7830. With a free supply of a repair fund 20 parts.

Similar results were also observed in some other parts (a half-axis, radiators, etc.). [12-14].

\section{Conclusions}

Thus, the replacement of parts of imported equipment by the reduction depends on a clear understanding of service organizations the task of ensuring uptime foreign equipment in Russia, when the Doctrine of Food Security of the State is carried out. Experience in the implementation of the recovered parts showed that the expected return of $77 \%$ for the operating company, the profitability of the proper implementation of the recovered parts service was more than $250 \%$. 


\section{References}

[1] Reid D. W., Garnett L. Bradford American Journal of Agricultural Economics Vol. 65, No. 2 (May, 1983), pp. 326-331

[2] Calculation of Tractor's Economical Life XIAO Ai-ling1,PAN Bin1,WANG Fu-lin2 (1. College of Agricultural Engineering, Tarim Agriculture University, Alar 843300, China; 2. College of Engineering, Northeast Agriculture University, Harbin 150030, China)

[3] Dykhuizen R.C., Smith M.F.J. Therm Spray Tech (1998) 7: 205. DOI: $10.1361 / 105996398770350945$

[4] ПродукцияДИМЕT (Products DIMET®) [online] [15.01.2018]. Available at: http://www.dimet.info/products/ (In Russian)

[5] Установка для напыления металла DYMET 405 (Installation for spraying metal DYMET 405) [online]. [15.01.2018]. Available at: http://regionfox.ru/katalog/oborudovanie-dlya-napyleniyametalla/ustanovka-dlya-napyleniya-metalla-dymet-405 (In Russian)

[6] Price list of equipment and supply [online] [10.04.2018]. Available at: http://www.dimet.info/price/

[7] Конкин Ю.А. Экономика ремонта (Economy repairs). Moscow. KolosPubl., 2005, 283 p. (In Russian)

[8] Стребков С.В., Срокина О.М., Экономическая оценка эффективности технологии восстановления детали (Economic evaluation of the effectiveness of technology of restoration parts.) Guidelines on the implementation of the economic part of the course and diploma projectBelgorod,«Belgorod State Agricultural University» Publ., 1996. 27 p.) (In Russian)

[9] Dikun Yu.V. The use of gas-dynamic coating to improve the operational performance parts / Yu.V.Dikun, V.A.Zemskov // Strengthening technology and coatings, - 2005, number 10, pp. $15-17$

[10]ШпилькоА.В. Руководство по подготовке бизнес-планов по внедрению технологий и сельскохозяйственной техники. (Guidelines for the preparation of business plans for the introduction of technologies and agricultural machinery). Moscow: VNIIESKH, 2008, 40 p. (In Russian)

[11]Справочная информация: "Минимальный размер оплаты труда в Российской Федерации" (Reference information: "The Minimum wage in the Russian Federation") [online] [10.04.2018]. Available at:

http://www.consultant.ru/document/cons_doc_LAW_15189/d3c83d33744eaf7b1b0b7d9e652022 7c2cb3a5b5/. (In Russian)

[12] Стребков С.В., Слободюк А.П. Оценка эффективности импортозамещения запасныхчастей для сельскохозяйственной техники. (Efficiency assessment of import substitution of agricultural machinery spare parts) Challenges and opportunities of innovative development of agrotechologies, Materials of the XIX International scientific and production conference, 24-26 May 2015, Belgorod, Russia. (In Russian)

[13]Стребков С.В., Слободюк А.П. Восстановление работоспособности деталей импортной сельскохозяйственной техники (Restoration of working capacity of parts of foreign agricultural machinery). Materials of the International distance research and practice conference «Important directions of scientific investigations of the XXI century: theory and practice»: collection of research papers, Voronezh, Russia, 5 (2014), pp.268-272. (In Russian)

[14] СтребковС.В., СлободюкА.П. Восстановление деталей импортной техники (Recovery of components imported machinery). Moscow, Proceedings GOSNITI. - 2014 - T.117, ch. 1. (In Russian) 